\title{
Hematological and Serum Biochemical Abnormalities Associated with a Suspected Case of Genital Squamous Cell Carcinoma in a Gray Nigerian Mare
}

\author{
Onyinyechukwu A. AGINA*, John I. IHEDIOHA \\ University of Nigeria, Faculty of Veterinary Medicine, Department of Veterinary Pathology and Microbiology, Nsukka, \\ Nigeria; onyinye.noel@unn.edu.ng(*orrespondingauthor)
}

\begin{abstract}
An 18-year-old gray mare (a crossbred Nigerian horse) was observed to have a proliferative tissue growth with multiple necrotic areas, which was suspected to be a genital squamous cell carcinoma. The mucous membrane of the eyes and gingiva of the mare were pale, and the animal was dull and insensitive, had an abnormal posture and gait, with conspicuous protruding proliferative tissue mass around the vagina and vulva. Blood samples for hematology analysis and serum biochemistry were collected from the jugular vein and determinations followed standard procedures. Hematological examination revealed that the mare had macrocytic anaemia, leukocytosis, neutrophilia, monocytosis, higher than normal erythrocyte sedimentation rate. Serum biochemical assays showed that serum activities of aspartate aminotransferase and alanine aminotransferase were slightly lower than normal. High serum alkaline phosphatase activity was recorded, with high serum total protein level that was mainly due to high serum globulin level. The mare also had a lower than normal total cholesterol. High serum creatinine level was observed. These hematological and serum biochemical findings are commonly associated with genital squamous cell carcinomas in animals and humans.
\end{abstract}

Keywords: blood, genital, neoplasm, non-pigmented skin, old gray mare, serum biochemistry

\section{Introduction}

Squamous cell carcinomas are locally invasive malignant neoplasms of the genitals, which are commonly diagnosed in horses (Bolin, 1999; Pimenta-Oliveira et al., 2011). This tumour can appear anywhere on the body, but it is most often located on non-pigmented skin near mucocutaneous junctions such as on the eyelids, nictating membrane, oral, pharyngeal and nasal mucosae, around the nostrils, vulva, prepuce, penis or anus (Schuh, 1986; Bolin, 1999; Pigatto et al., 2010). The eyelid and related structures represent the most common site, accounting for $40-50 \%$ of cases, followed by male ( $25 \%$ of cases) and female ( $10 \%$ of cases) genitalia (Bolin, 1999; Knottenbelt and McGarry, 2009).

The tumors are raised, fleshy, often ulcerated or infected and may have an irregular surface (Valentine, 2006). Rarely, primary squamous cell carcinomas (SCC) develop in the limbs, esophagus, stomach (non-glandular portion), nasal passages and sinuses, the hard palate, gums, guttural pouches and lung (Beuchner-Maxwell, 2009).

The age of affected horses ranges from 1 to 31 years (Bolin, 1999), but the tumour occur commonly in aged/old horses (Buechner-Maxwell, 2009). Sex predisposition has not been established, but SCC is known to affect more female than male horses (Bolin, 1999). Horses with lightly pigmented skin, such as those with a gray hair coat or white faces, are especially prone to developing SCC (Beuchner-Maxwell, 2009) and some breeds such as the Thoroughbred, Quarter Horse, Appaloosa, Clydesdale may have a genetic predisposition (Knottenbett and
McGarry, 2009). This neoplasia has been reported to affect old gray female horses, pintos and individual horses with little or no pigmentation around the mucocutaneous junctions such as the anus when exposed to ultra-violet radiation for a long period of time (Burney et al., 1992; Miller, 2007; Beuchner-Maxwell, 2009; Knottenbett and McGarry, 2009). Other predisposing factors include trauma (MacFadden and Pace, 1991), infection by equine papillomavirus type 2 (Bogaert et al., 2012), chronic irritation of cutaneous wounds leading to a tissue metaplasia (Kusewitt and Rush, 2007) and pseudohyperparathyroidism (Karcher et al., 1990).

Clinical signs of the disease include inappetence, lethargy, weight loss, dyschezia and hematochezia (Wilson, 1994).

There is paucity of information in the area of hematology and serum biochemistry abnormalities associated with genital squamous cell carcinoma in horses; hence, the current case report documented the hematological and serum biochemistry abnormalities associated with genital squamous cell carcinoma in a mare.

\section{Materials and Methods}

An 18-year old Nigerian gray mare presented for sale at Obollo Afor horse lairage, Udenu local Government Area of Enugu State, was observed to have a proliferative mass which was fleshy, raised with an irregular surface and multifocal necrotic areas (black areas) around the vulva and vagina. Medical history was unavailable because it was one of the horses sold and transported from the Northern to the Eastern part of Nigeria, which are usually re-sold 
142

and slaughtered for meat. The mare's age was estimated based on tooth eruption, wear and appearance of Galvayne's groove (Ensminger, 1969).

Before blood sample was collected, the mare was subjected to physical examination.

Histopathological examination was not possible because of limiting factors such as uncooperative animal handler and buyer's reluctance to allow sample (tissue) collection.

Blood samples were collected from the jugular outflow at slaughter, into two sets of sample bottles: one bottle was allowed to stand for $30 \mathrm{~min}$ to clot and serum was separated by centrifugation, while the other contained Na EDTA, to prevent clotting. Hematological and serum biochemical determinations followed standard procedures (Thrall and Weiser, 2002; Burtis et al., 2008). A presumptive diagnosis of genital squamous cell carcinoma was made on the gross appearance of the neoplasm and its location.

\section{Results}

Physical examination revealed pale mucous membranes of the eye, gingiva and emaciation. There were no ocular and nasal discharges and no vesicles, erosions or ulcers in the buccal cavity. The skin was free of alopecia, nodules and ectoparasites. The mare exhibited dullness and insensitivity. The perineum was free of diarrheic feces or adult worms, but the vulva had a proliferative fleshy mass (Fig. 1). There was no evidence of vaginal discharge or hemorrhage. The mare also had an abnormal gait and posture.

The hematological evaluation showed that the packed cell volume of the mare was $26 \%$; (reference value $43.21 \pm 0.77 \%$ ), while the red blood cell count was $3.65 \times 10^{6} / \mu \mathrm{l}$ (reference value $\left.8.69 \pm 0.16 \times 10^{6} / \mu \mathrm{l}\right)$ and the hemoglobin concentration was 8.88 $\mathrm{g} / \mathrm{dl}$ (reference value $15.11 \pm 0.29 \mathrm{~g} / \mathrm{dl})$. The mean corpuscular volume of the mare was $71.23 \mathrm{fl}$ (reference value $50.04 \pm 0.55 \mathrm{f}$ ) while the mean corpuscular hemoglobin was $24.33 \mathrm{pg}$ (reference value $17.71 \pm 0.38 \mathrm{pg}$ ) and mean corpuscular hemoglobin concentration was $34.15 \mathrm{~g} / \mathrm{dl}$ (reference value $35.30 \pm 0.72 \mathrm{~g} / \mathrm{dl}$ ). The erythrocyte sedimentation rate recorded for the mare was $57.63 \mathrm{~mm} / 20 \mathrm{mins}$ (reference value $28.19 \pm 3.57 \mathrm{~mm} / 20 \mathrm{mins}$ ). The total leukocyte count of the mare was $23.05 \times 10^{3} / \mu$; (reference value $9.53 \pm 0.31 \times 10^{3} / \mu \mathrm{l}$ ) with the band neutrophil count of $2.77 \times 10^{3} / \mu \mathrm{l}$ (reference value $0.28 \pm 0.04 \times 10^{3} / \mu \mathrm{l}$ ) and segmented neutrophil count of $15.44 \times 10^{3} / \mu l$ (reference value $\left.4.77 \pm 0.23 \times 10^{3} / \mu l\right)$. The lymphocyte count of the mare was 4.49 $\times 10^{3} / \mu \mathrm{l}$; (reference value $\left.4.19 \pm 0.19 \times 10^{3} / \mu \mathrm{l}\right)$, while the monocyte count was $0.35 \times 10^{3} / \mu \mathrm{l}$ (reference value $-0.03 \pm 0.01 \times$ $10^{3} / \mu \mathrm{l}$ ) and platelet count $350 \times 10^{3} / \mu \mathrm{l}$ (reference value $326.94 \pm$ $\left.16.30 \times 10^{3} / \mu \mathrm{l}\right)$. No eosinophils and basophils were found in the blood smear.

The serum biochemistry results showed that the serum aspartate aminotransferase activity of the mare was $90.11 \mathrm{IU} / \mathrm{L}$ (reference value $95.09 \pm 1.14 \mathrm{IU} / \mathrm{L}$ ) while the serum alanine aminotransferase was $5.87 \mathrm{IU} / \mathrm{L}$ (reference value $9.44 \pm 0.69$ IU/L) and the serum alkaline phosphatase activity was 99.51 IU/L (reference value $70.49 \pm 2.55 \mathrm{IU} / \mathrm{L}$ ). The serum total protein levels of the mare was $7.72 \mathrm{~g} / \mathrm{dl}$ (reference value $6.83 \pm$ $0.07 \mathrm{~g} / \mathrm{dl}$ ); the serum albumin level was $2.62 \mathrm{~g} / \mathrm{dl}$ (reference value $3.35 \pm 0.05 \mathrm{~g} / \mathrm{dl}$ ), while the serum globulin level was $5.10 \mathrm{~g} / \mathrm{dl}$ (reference value $3.48 \pm 0.08 \mathrm{~g} / \mathrm{dl}$ ). The mare's serum total cholesterol value was $69.56 \mathrm{mg} / \mathrm{dl}$ (reference value $108.42 \pm 3.41$ $\mathrm{mg} / \mathrm{dl}$ ), while the serum total bilirubin was $3.37 \mathrm{mg} / \mathrm{dl}$ (reference value $3.43 \pm 0.13 \mathrm{mg} / \mathrm{dl})$. The serum creatinine level of the mare was $2.00 \mathrm{mg} / \mathrm{dl}$ (reference value $1.31 \pm 0.04 \mathrm{mg} / \mathrm{dl}$ ), while the

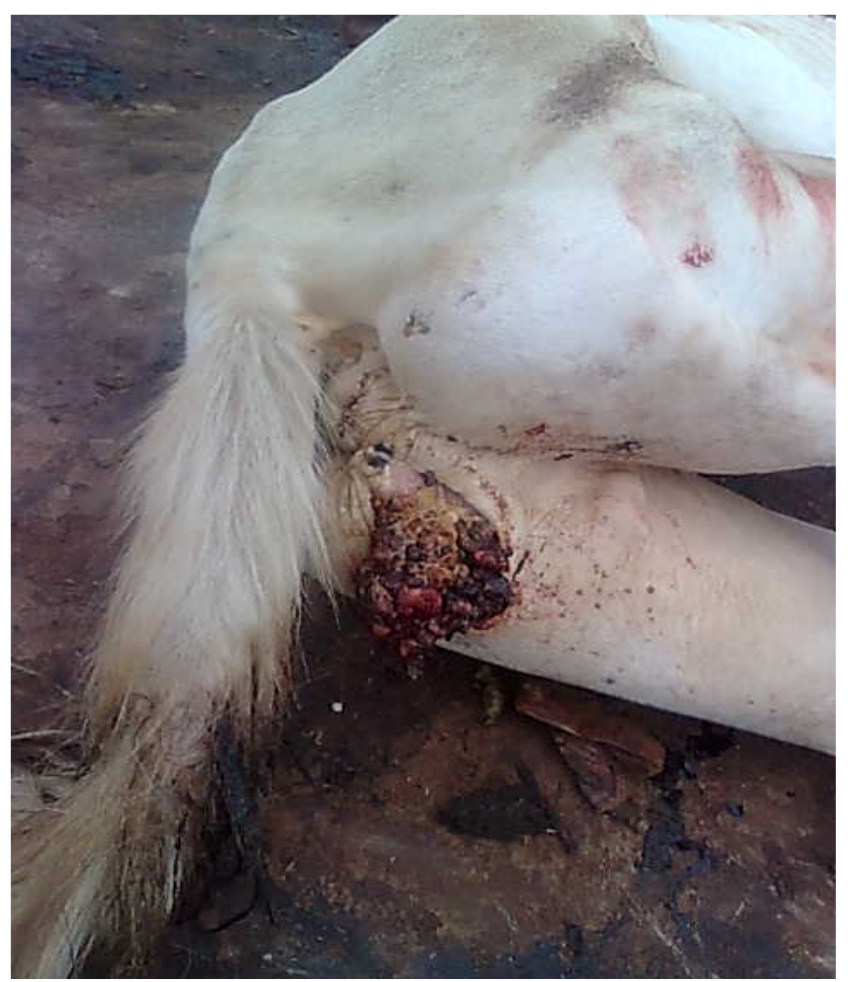

Fig. 1. Proliferative fleshy mass with an irregular surface and multifocal necrotic areas protruding from the vagina and vulva of a mare (suspected case of squamous cell carcinoma)

serum urea level was $32.00 \mathrm{mg} / \mathrm{dl}$ (reference value $32.33 \pm 0.88$ $\mathrm{mg} / \mathrm{dl})$.

\section{Discussion}

The very low packed cell volume, red blood cell count and hemoglobin concentration recorded higher than normal mean corpuscular volume, which are indicative of anaemia of the macrocytic type. Macrocytic anaemia is commonly associated with blood loss (Coles, 1986; Stockham and Scott, 2008) and it is thought that there was blood loss in the mare from the necrotic areas of the proliferating neoplasm.

The leukocytosis associated with neutrophilia and monocytosis recorded in the mare is believed to be the body's reaction to the presence of the proliferating neoplasm. The findings of leukocytosis, neutrophilia and monocytosis were in agreement with earlier reports on genital squamous cell carcinomas (Kato et al., 1999; Doraiswamy et al., 2010).

The very high erythrocyte sedimentation rate recorded for the mare may partly be due to tissue destruction associated with the neoplasm and partly due to the anaemia (Coles, 1986; Stockham and Scott, 2008). The finding of higher than normal erythrocyte sedimentation rate in the mare presently being reported on concurs with the reported high erythrocyte sedimentation rate in patients with genital squamous cell carcinomas (Khan and Bagchi, 2011; Sari et al., 2015).

The serum alkaline phosphatase activity recorded in the mare was higher than normal; this may be as a result of a possible tumour metastasis to bone or liver or specific ALP enzyme induction by the neoplastic cells (Ihedioha, 2003; Kumar et al., 2003). The higher serum ALP recorded in this present case report concurs with findings earlier reported by Merza et al. (2010) and Aminian et al. (2011). 
The higher than normal serum total protein, which was due mainly to high serum globulin levels, recorded in the present report was believed to be due to increased antibody response to the neoplasm; the result is in agreement with the reports of Olsen (1992), McKenzie (1997) and Merza et al. (2010).

The low serum cholesterol recorded in this present report was in agreement with reports of Ghosh et al. (2011) and Singh et al. (2013)

\section{Conclusions}

Based on the findings in the current study, it was concluded that the suspected case of genital squamous cell carcinoma in the mare reported was associated with macrocytic anaemia, leukocytosis, neutrophilia, monocytosis, higher than normal erythrocyte sedimentation activity, serum total protein and globulin levels, but with lower than normal serum total cholesterol levels, effects commonly associated with genital squamous cell carcinomas.

\section{References}

Aminian A, Karimian F, Mirsharifi R, Alibakhshi A, Hasani SM, Dashti $\mathrm{H}$,Jahangiri Y, Ghaderi H, Meysamie A (2011). Correlation of serum alkaline phosphatase with clinicopathological characteristics of patients with oesophageal cancer. Eastern Mediteranean Health Journal 17(11):862-866.

Beuchner-Maxwell V (2009). Skin tumours. In: Norman ER, Kim A Sprayberry (Eds). Current Therapy in Equine Medicine (6th ed). St. Louis Elsevier Health Sciences pp 692-697.

Bogaert L, Willemsen, A, Vanderstraeten, E, Bracho, MA, De Baere C, Bravo IG, Martens A (2012). $\mathrm{EcPV}_{2}$ DNA in equine genital squamous cell carcinomas and normal genital mucosa. Veterinary Microbiology 158(1-2):33-41.

Bolin DC (1999). Cutaneous neoplasms of horses. Equine Disease Quarterly 7:4.

Burney DP, Theisen SK, Schmitz DG (1992). Identifying and treating squamous cell carcinoma of horses. Veterinary Medicine 6:558.

Burtis CA, Ashwood ER, Bruns DE (2008). Tietz fundamentals of clinical chemistry, 6th ed. Saunders Elsevier, Missouri, USA.

Coles EH (1986). Veterinary clinical pathology. 4th ed. WB Saunders, Philadelphia.

Doraiswamy VA, Biboa J, Obafemi A, Goldschmid M (2010). Leukocytosis and hypercalcemia: a rare combination of paraneoplastic features in squamous cell penile cancer. South Medical Journal 103(5):474476.

Ensminger ME (1969). Horses and horsemanship. 4th ed. The interstate, Danville, Illinois.

Ghosh G, Jayaram KM, Patil RV, Malik S (2011). Alterations in serum lipid profile patterns in oral squamous cell carcinoma patients. Journal of Contemporary Dental Practice 12(6):451-456.

Ihedioha JI (2003). Basic principles of general pathology. AP Express Publishers Limited \& FERH,Nsukka, Nigeria.

Karcher LF, Le Nel J, Turner BF, Reimers TJ, Tennant BC (1990). Pseudohyperparathyroidism in a mare associated with squamous cell carcinoma of the vulva. The Cornell Veterinarian 80(2):153-162.
Kato N, Yasukawa K, Onozuka T, Kimura K (1999). Paraneoplastic syndromes of leukocytosis and hypercalcaemia associated with squamous cell carcinoma associated with squamous cell carcinoma. Journal of Dermatology 26(6):352-358.

Khan K, Bagchi D (2011). Squamous cell carcinoma arising in a testicular teratoma and presenting as Sister Mary Joseph nodule. Journal of Surgical Technique and Case Report 3(2):99-101.

Knottenbelt DC, McGarry J (2009). Neoplastic conditions. In: Pascoe's principles and practice of equine dermatology. London, WB Saunders pp 377-439.

Kumar V, Cotran RS, Robbins SF (2003). Robbin's basic pathology. 7th Ed Saunders, Philadelphia.

Kusewitt DF, Rush LJ (2007). Neoplasia and tumour biology. In: McGavin MD, Zachary JF (Eds). Pathologic basis of veterinary disease. St. Louis: Mosby Elsevier pp 1263-1315.

MacFadden KF, Pace IW (1991). Clinical manifestations of squamous cell carcinoma in horses. Compendium on Continuing Education for Practicing Veterinarians 13:669.

McKenzie EC, Mills JN, Botton JR (1997). Gastric squamous cell carcinoma in 3 horses. Australian Veterinary Journal 75(7):480-483.

Merza KS, Alaaraji SB, Abdullah BH (2010). Comparative study on lactate dehydrogenase, alkaline phosphatase and immunoglobulins in serum and saliva of acute leukemia and oral squamous cell carcinoma patients. Iraqi Journal of Science 51(2):262-270.

Miller CD (2007). Infectious and neoplastic conditions of the vulva and perineum. In: Samper JC, Pycock JF, McKinnon AO (Eds). Current Therapy in Equine Reproduction. Saunders, St. Louis, Missouri, USA pp 161-165.

Olsen SN (1992). Squamous cell carcinoma of the equine stomach: a report of five cases. The Veterinary Record 131(8):170-173.

Pigatto JAT, Marks FS, Hünning PS, Pereira FQ, Almeida AC, Gomes C, Albuquerque L, Driemeier D (2010). Corneal squamous cell carcinoma in a dog. Acta Scientiae Veterinariae 38(2):197-200.

Pimenta-Oliveira A, Oliveira-Filho JP, Cagnini DQ, Badial PR, CisnerosAlvarez E, Laufer-Amorim R, Prestes NC (2011). Squamous cell carcinoma in vaginal fundus in a Brahman cow. Arquivo Brasileiro de Medicina Veterinaria eZootecnia 63(3):749-752.

Sari F, Sarikaya AM, Suren D, Eren M, Yilmaz B (2015). Barded-Biedl syndrome with vulva carcinoma presented with acute renal failure: a case report. Hippokratia 19(2):176-178.

Schuh JC (1986). Squamous cell carcinoma of the oral, pharyngeal and nasal mucosa in the horse. Veterinary Pathology 23(2):205-207.

Singh S, Ramesh V, Premalatha B, Prashad KV, Ramadass K (2013). Alterations in serum lipid profile patterns in oral cancer. Journal of Natural Science Biology and Medicine 4(2):374-378.

Stockham SL, Scott MA (2008). Fundamentals of veterinary clinical pathology. 2nd ed. Blackwell Publishing Iowa, USA.

Thrall MA, Weiser MG (2002). Haematology. In: Hendrix CM (Ed). Laboratory procedures for veterinary technicians, 4th ed. Mosby Inc, Missouripp 29-74.

Valentine BA (2006). Neoplasia. In: Bertone J (Ed). Equine. Geriatric medicine and surgery. St. Louis Elsevier Health Sciences pp 147-167.

Wilson DA (1994). Management of perianal squamous cell carcinoma with permanent colostomy in a mare. Journal of American Veterinary Medical Association 205(10):1430-1431. 